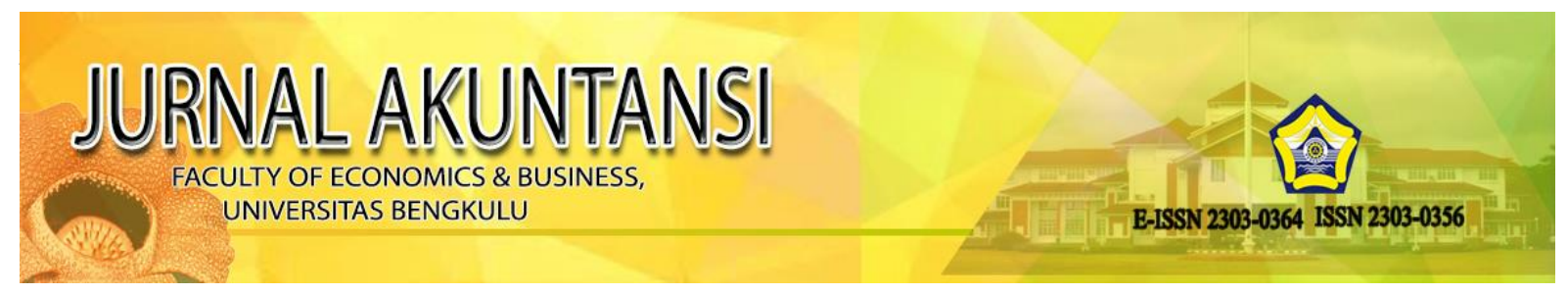

\title{
GAYA KEPEMIMPINAN, KOMITMEN ORGANISASI DAN AKUNTABILITAS TERHADAP ORGANIZATION CITIZENSHIP BEHA VIOR DI INSTITUSI MILITER (TNI-AD) KOTA BENGKULU
}

\author{
Nila Aprila1) , Eka Sepriani ${ }^{2)}$ \\ Fakultas Ekonomi dan Bisnis Universitas Bengkulu \\ nilaaprila@unib.ac.id ${ }^{1}$, Ekaa_adjj@yahoo.co.id
}

\begin{abstract}
This research evaluates the effect of leadership style, organizational commitment and accountability towards organizational behavior in Military Institution in Indonesia. Data was collected by survey method in TNIAD located in Kota Bengkulu. One hundred seventy questionaires gathered and analized with smartPLS. The result of this research shows that leadership style, organizational commitment and accountability influences organization citizeship behavior. This research inspired by the phenomenon that there is little research on military area regarding accountability, either in Indonesia or in the world. Thus, this research will give a siginificant literature contribution based on the empirical data analyzes in Military Institution in Indonesia.
\end{abstract}

Keywords: leadership style, organizational commitment, accountability and organization citizenship behavior.

\section{PENDAHULUAN}

\section{Latar Belakang}

Akuntabilitas adalah isu sentral dalam penyelenggaraan tata kelola pemerintah yang baik atau lebih dikenal dengan istilah "Good Government Governance," dan dalam praktik pengukuran kinerja, akuntabilitas dipaparkan dalam bentuk laporan pertanggungjawaban program kegiatan, capaian kinerja, evaluasi dan analisis capaian kinerja. Laporan Akuntabilitas Kinerja Instansi Pemerintah (LAKIP) yang dibuat dan dilaporkan oleh instansi pusat tidak dapat menjadi salah satu acuan evaluasi dan pengukuran kinerja secara sepihak, namun perlu bukti - bukti dan pengamatan lain sehingga LAKIP tersebut benar - benar reliabel dan relevan digunakan sebagai informasi yang dapat menciptakan keputusan maupun kebijakan yang efektif. Penyusunan LAKIP tentu berdasarkan realita yang terjadi disuatu organisasi sipil maupun militer yang tidak luput dari peran individu dan kelompok yang digambarkan erat dengan gaya kepemimpinan dan komitmen organisasi atau institusi tersebut serta faktor lain yang secara tidak langsung berpengaruh terhadap komitmen organisasi maupun gaya kepemimpinan. Pada organisasi atau institusi militer, gaya kepemimpinannya bersifat komando dan lebih formal dari pada organisasi atau institusi sipil, namun secara akuntabilitas, terutama mengenai akuntabilitas keuangan setiap organisasi dituntut akan pelaporan yang sama. Akuntabilitas diharapkan mampu mendukung reformasi birokrasi, seperti yang diamanatkan di Undangundang no 17 tahun 2007 tentang Rencana Pembangunan Jangka Panjang Nasional 2005-2025. Reformasi birokrasi di Indonesia dilakukan untuk membangun aparatur negara yang mendukung keberhasilan pembangunan bidang lainnya. Keberhasilan reformasi birokrasi salah satunya ditandai dengan peningkatan kinerja aparatur negara karena pembangunan aparatur negara diyakini mampu meningkatkan kinerja institusi pemerintah. Oleh sebab itu, kinerja menjadi bahasan penting dalam governance dan 
akuntabilitas. Kinerja pemerintah selalu terkait erat dengan perilaku kerja aparatur negara. Perilaku kerja dalam hal ini disebut organization citizenship behaviour.

Organization citizenship behavior (OCB) biasanya disebut perilaku kewarganegaraan adalah tindakan ekstra yang melebihi deskripsi peran karyawan. Tindakan ekstra yang dilakukan karyawan contohnya menolong rekan, berpartisipasi aktif, menggunakan waktu kerja secara efektif, tidak membolos ketika hari kerja dan lain sebagainya. Dengan kata lain karyawan tidak hanya mengerjakan tugas pokoknya (in-role) saja tetapi mengerjakan tugas ekstra yang membuat nilai lebih untuk keefektifan organisasi. Organizational citizenship behavior (selanjutnya $O C B$ ) merupakan model kegiatan yang membuat organisasi secara instrinsik dapat bekerja sama (Katz dan Khan,1966 dalam Ariani, 2011). Menurut Ariani (2011) organisasi efektif apabila individu yang masuk kedalam organisasi itu mau menunjukkan peran dengan kriteria minimal untuk mencapai kinerjanya dan mempunyai perilaku yang inovatif dan sportif dalam menjalankan fungsi organisasi. Belum ada penelitian sektor publik (pemerintah khususnya) di Indonesia yang dilakukan di dunia militer. Padahal, dari segi urgensi keuangan, porsi anggaran belanja negara yang disisihkan dari keseluruhan APBN Indonesia di bidang pertahanan tidaklah sedikit. Dari data pokok APBN yang dikeluarkan oleh Kementrian Keuangan tahun 2006-2012, setiap tahunnya, 5-7\% dari total pembelanjaan APBN dialokasikan ke sektor pertahanan. Pada tahun 2006, pertahanan mengambil porsi 5,9\% total APBN. Angka ini merangkak naik menjadi 6,7 \% di tahun 2012 dan di tahun 2013 (RAPBN). Lonjakan anggaran di bidang pertahanan telah mencapai 3 kali lipat dari tahun 2007 hingga tahun 2013, yaitu dari 30,7 triliun rupiah menjadi 81,8 triliun rupiah. Belanja pertahanan ditujukan untuk investasi keamanan dan kedaulatan Indonesia, sehingga iklim mampu membantu tugas TNI untuk menegakkan kedaulatan Indonesia yang mendukung pembangunan.

Organizational citizenship behavior $(O C B)$ adalah perilaku individu yang dilakukan secara sukarela tanpa mengharap reward dari organisasi/perusahaan. $O C B$ ini merupakan salah satu perilaku individu yang dapat mempengaruhi kinerja. Luthans (2006:251) menyatakan bahwa Individu yang menunjukkan $O C B$ memiliki kinerja lebih baik dan menerima evaluasi kinerja yang lebih tinggi. $O C B$ juga berkaitan dengan kinerja dan evektivitas organisasi. Oleh sebab itu seorang pimpinan harus dapat meningkatkan $O C B$ karyawannya. Penelitian Organ \& Padsakoff (2006:199) bahwa $O C B$ berpengaruh terhadap kinerja organisasi, begitu juga hasil penelitian Yun Su (2007). Ia mencoba menjelaskan bagaimana service-oriented organizational citizenship behaviour (OCB) menengahi (sebagai mediator) antara hubungan manajemen sumberdaya manusia berkinerja tinggi (high- performance human resource practices) dengan kinerja organisasi yang diukur dari turnover dan productivity.

Manfaat $O C B$ adalah dapat meningkatkan evektivitas unit kerja, meningkatkan produktivitas rekan kerja, meningkatkan kemampuan organisasi untuk menarik dan mempertahankan karyawan terbaik, menghemat sumber daya yang dimiliki manajemen dan organisasi secara keseluruhan, membantu menghemat energi sumber daya yang langka untuk memelihara fungsi kelompok, menjadi sarana efektif untuk mengkoordinasi kegiatan-kegiatan kelompok kerja, meningkatkan stabilitas kinerja organisasi, serta meningkatkan kemampuan organisasi untuk beradaptasi dengan perubahan lingkungan. Dengan demikian, $O C B$ dapat meningkatkan kinerja karyawan yang pada akhirnya juga akan meningkatkan kinerja organisasi. Beberapa penelitian menunjukkan bahwa $O C B$ berpengaruh positif terhadap kinerja karyawan dan efektifitas organisasi. Tetapi dalam konteks sektor publik, khususnya sektor militer, kinerja dan efektivitas mereka masih di pertanyakan. Kinerja sektor publik banyak mempertimbangkan kinerja formal (in role) dan mengabaikan dimensi perilaku kerja seperti $O C B$ (extra-role), motif altrusitik dan 
komitmen (Camilleri dan Heidjen, 2007). Sehingga penting untuk mengetahui dan memahami identifikasi pegawai yang berpengaruh terhadap $O C B$.

Di tengah urgensi akan akuntabilitas dan pengukuran kinerja, sangat ironis bila riset mengenai akuntabilitas dan kinerja di sektor militer di Indonesia tidak tersentuh. Jarangnya penelitian di sektor militer mungkin akibat dari birokrasi yang sulit ditembus oleh para peneliti dan masyarakat umum. Oleh sebab itu, penelitian ini mencoba menutup gap tersebut dengan memulai penelitian yang bertemakan akuntansi publik sektor militer, khususnya terkait akuntabilitas, gaya kepemimpinan, komitmen organisasi, dan organization citizenship behavior.

Penelitian ini adalah penelitian replikasi, dikembangkan dari penelitian Mahmudah dan Mapuasari (2013) dengan memasukkan variabel tambahan yaitu gaya kepemimpinan sesuai saran pada penelitian sebelumnya. Populasi dalam penelitian ini adalah seluruh pegawai angkatan darat (TNI-AD) kota Bengkulu, sedangkan sampel dalam penelitian ini adalah Sampel dalam penelitian ini adalah beberapa orang anggota TNI-AD yang bertugas di Korem 041/Gamas, Kodim 0407 dan Kompi Senapan B/JY kota Bengkulu.

Berdasarkan latar belakang diatas maka rumusan masalah dalam penelitian ini adalah:

1. Apakah gaya kepemimpinan berpengaruh terhadap organization citizenship behavior?

2. Apakah komitmen organisasi berpengaruh terhadap organization citizenship behavior?

3. Apakah akuntabilitas berpengaruh terhadap organization citizenship behavior?

\section{KERANGKA TEORITIS DAN HIPOTESIS}

\section{Gaya Kepemimpinan}

Kepemimpinan memegang peranan yang sangat penting dalam manajemen organisasi. Kepemimpinan dibutuhkan manusia karena adanya keterbatasan- keterbatasan tertentu pada diri manusia. Dari sinilah timbul kebutuhan untuk memimpin dan dipimpin. Kepemimpinan didefinisikan ke dalam ciri-ciri individual, kebiasan, cara mempengaruhi orang lain, interaksi, kedudukan dalam oragnisasi dan persepsi mengenai pengaruh yang sah. Kepemimpinan adalah kemampuan untuk mempengaruhi orang lain untuk mencapai tujuan dengan antusias (David, Keith, 1985). Menurut Veitzhal Rivai (2004), kepemimpinan adalah proses mempengaruhi atau memberi contoh kepada pengikutpengikutnya lewat proses komunikasi dalam upaya mencapai tujuan organisasi.

Menurut Achmad Suyuti (2001) yang dimaksud dengan kepemimpinan adalah proses mengarahkan, membimbing dan mempengaruhi pikiran, perasaan, tindakan dan tingkah laku orang lain untuk digerakkan ke arah tujuan tertentu. Gaya kepemimpinan pada dasarnya mengandung pengertian sebagai suatu perwujudan tingkah laku dari seorang pemimpin yang menyangkut kemampuannya dalam memimpin. Perwujudan tersebut biasanya membentuk suatu pola atau bentu tertentu. Pengertian gaya kepemimpinan yang demikian ini sesuai dengan pendapat yang disampaikan oleh Davis dan Newstrom (1995) yang menyatakan bahwa pola tindakan pemimpin secara keseluruhan seperti yang dipersepsikan atau diacu oleh bawahan. Gaya kepemimpinan mewakili filsafat, ketrampilan, dan sikap pemimpin dalam politik.

\section{Teori Kepemimpinan}


Gaya kepemimpinan dari seorang pemimpin, pada dasarnya dapat diterangkan melalui tiga aliran teori sebagai berikut :

1. Teori Genetis (Keturunan)

Inti dari teori ini menyatakan bahwa "leader are born and not made" (pemimpin itu dilahirkan sebagai bakat dan bukannya dibuat). Para penganut aliran teori ini berpendapat bahwa seorang pemimpin akan menjadi pemimpin karena ia telah dilahirkan dengan bakat kepemimpinannya. Dalam keadaan yang bagaimanapun seseorang ditempatkan karena ia telah ditakdirkan menjadi pemimpin, sesekali kelak ia akan timbul sebagai pemimpin. Berbicara mengenai takdir, secara filosofis pandangan ini tergolong pada pandangan fasilitas atau determinitis.

2. Teori Sosial

Jika teori pertama di atas adalah teori yang ekstrim pada satu sisi, maka teori inipun merupakan ekstrim pada sisi lainnya. Inti aliran teori sosial ini ialah bahwa "leader are made and not born" (pemimpin itu dibuat atau dididik dan bukannya kodrati). Jadi teori ini merupakan kebalikan inti teori genetika. Para penganut teori ini mengetengahkan pendapat yang mengatakan bahwa setiap orang bisa menjadi pemimpin apabila diberikan pendidikan dan pengalaman yang cukup.

3. Teori Ekologis

Kedua teori yang ekstrim di atas tidak seluruhnya mengandung kebenaran, maka sebagai reaksi terhadap kedua teori tersebut timbullah aliran teori ketiga. Teori yang disebut teori ekologis ini pada intinya berarti bahwa seseorang hanya akan berhasil menjadi pemimpin yang baik apabila ia telah memiliki bakat kepemimpinan. Bakat tersebut kemudian dikembangkan melalui pendidikan yang teratur dan pengalaman yang memungkinkan untuk dikembangkan lebih lanjut. Teori ini menggabungkan segi-segi positif dari kedua teori terdahulu sehingga dapat dikatakan merupakan teori yang paling mendekati kebenaran.

\section{Tipologi Kepemimpinan}

Dalam praktiknya, dari ketiga gaya kepemimpinan tersebut berkembang beberapa tipe kepemimpinan; di antaranya adalah sebagian berikut (Siagian,1997).

1. Tipe Otokratis

2. Tipe Militeristis

3. Tipe Paternalistis

4. Tipe Karismatik

5. Tipe Demokratis

Secara implisit tergambar bahwa untuk menjadi pemimpin tipe demokratis bukanlah hal yang mudah. Namun, karena pemimpin yang demikian adalah yang paling ideal, alangkah baiknya jika semua pemimpin berusaha menjadi seorang pemimpin yang demokratis. Ishak Arep, Hendri Tanjung, (2003) mengemukakan empat (4) gaya kepemimpinan yang lazim digunakan, antara lain

1. Democratic Leadership, yakni suatu gaya kepemimpinan yang menitikberatkan pada kemampuan untuk menciptakan moral dan kemampuan untuk menciptakan kepercayaan.

2. Directorial/Authocratic Leadership, yakni suatu gaya kepemimpinan yang menitikberatkan kepada kesanggupan untuk memaksakan keinginannya yang mampu mengumpulkan pengikut untuk kepentingan pribadi dan golongannya dengan kesediaan menerima segala resiko apapun. 
3. Paternalitic Leadership, yakni bentuk gaya kepemimpinan pertama (democratic) dan kedua (dictorial) diatas, yang dapat diibaratkan dengan sistem diktator yang berselimutkan demokratis.

4. Free Rein Leadership, yakni gaya kempimimpinan yang $100 \%$ menyerahkan sepenuhnya kebijaksanaan pengoprasian manajemen sumber daya manusia kepada bawahannya dengan hanya berpegang kepada ketentuan-ketentuan pokok yang ditentukan oleh atasan mereka.

Menurut Heidjrachman dan Husnan (2002:173) seorang pemimpin harus memiliki sifat perceptive artinya mampu mengamati dan menemukan kenyataan dari suatu lingkungan. Untuk itu ia harus mampu melihat, mengamati, dan memahami keadaan atau situasi tempat kerjanya, dalam artian bagaimana para bawahannya, bagaimana keadaan organisasinya, bagaimana situasi penugasannya, dan juga tentang kemampuan dirinya sendiri. la harus mampu menyesuaikan diri dengan lingkungannya. Maka dari itu dalam memilih gaya kepemimpinan yang akan digunakan, perlu dipertimbangkan berbagai faktor yang mempengaruhinya.

\section{Komitmen Organisasi}

Menurut Wiyono (1999: 34), komitmen adalah tekad bulat untuk melakukan sesuatu dengan niat yang sungguh-sungguh melakukan. Komitmen yang baik adalah komitmen yang dimulai dari pimpinan. Sedangkan menurut Robbins (2001:140), komitmen pegawai pada suatu organisasi adalah suatu keadaan di mana karyawan memihak kepada organisasi tertentu dan tujuan-tujuannya, serta berniat memelihara keanggotaannya dalam organisasi itu. Pendapat lain dikemukakan oleh Pradiansyah (1999:31) yang menguraikan bahwa komitmen merupakan konsep manajemen yang menempatkan sumber daya manusia sebagai figur sentral dalam organisasi usaha. Tanpa komitmen, sukar mengharapkan partisipasi aktif dan mendalam dari sumber daya manusia. Tapi komitmen bukanlah sesuatu yang dapat hadir begitu saja. Komitmen harus dilahirkan. Oleh sebab itu komitmen harus dipelihara agar tetap tumbuh dan eksis disanubari sumber daya manusia. Dengan cara dan teknik yang tepat pimpinan yang baik bisa menciptakan dan menumbuhkan komitmen.

Allen dan Meyer (1990: 235) mengklasifikasikan komitmen organisasional ke dalam tiga dimensi, yaitu: komitmen afektif (affective commitment), komitmen continuance (continuance commitment), dan komitmen normatif (normative commitment). Penjelasan dari ketiga dimensi komitmen tersebut adalah sebagai berikut :

1. Komitmen afektif (affective commitment) yaitu keterlibatan emosi pekerja terhadap organisasi. Komitmen ini dipengaruhi dan atau dikembangkan apabila keterlibatan dalam organisasi terbukti menjadi pengalaman yang memuaskan. Organisasi memberikan kesempatan untuk melakukan pekerjaan dengan semakin baik atau menghasilkan kesempatan untuk mendapatkan skill yang berharga.

2. Komitmen berkesinambungan (continuance commitment) yaitu keterlibatan komitmen berdasarkan biaya yang dikeluarkan akibat keluarnya pekerja dari organisasi. Komitmen ini dipengaruhi dan atau dikembangkan pada saat individu melakukan investasi. Investasi tersebut akan hilang atau berkurang nilainya apabila individu beralih dari organisasinya.

3. Komitmen normatif (normative commitment) yaitu keterlibatan perasaan pekerja terhadap tugas-tugas yang ada di organisasi. Komitmen normatif dipengaruhi dan atau dikembangkan sebagai hasil dari internalisasi tekanan normatif untuk melakukan 
tindakan tertentu, dan menerima keuntungan yang menimbulkan perasaan akan kewajiban yang harus dibalas.

\section{Akuntabilitas}

Akuntabilitas dapat dibedakan karena faktor lingkungan yang mempengaruhi sikap dan watak kehidupan manusia, sehingga dalam hal ini akuntabilitas dapat dibedakan menjadi dua jenis, yaitu akuntabilitas internal dan akuntabilitas eksternal. Akuntabilitas internal adalah akuntabilitas yang mencerminkan pertanggungjawaban seseorang terhadap Tuhannya. Sedangkan akuntabilitas eksternal adalah pertanggungjawaban seseorang kepada lingkungannya, baik lingkungan formal maupun lingkungan masyarakat.

Akuntabilitas berasal dari bahasa Prancis kuno yaitu comper atau conter yang berarti to account atau to enumerate (Cut dan Muray, 2000). Secara eksplisit, arti to account sendiri adalah untuk menghitung. Bovens (2007) menegaskan secara etymological dan akar historis bahwa akuntabilitas datang dari akuntansi. Menurut kamus oxford, akuntabilitas berarti tanggung jawab seseorang untuk memberikan perhitungan dan kejelasan atas sesuatu. Makna akuntabilitas kemudian diperluas dengan berbagai penelitian yang mengembangkan akuntabilitas dalam berbagai konteks. Akbar (2012) makna akuntabilitas tergantung pada konteks yang melekat pada kata akuntabilitas.

Sinclair (1995) dalam Hartati (2008) menyebutkan lima bentuk akuntabilitas, yaitu akuntabilitas politik, akuntabilitas publik, akuntabilitas manajerial, akuntabilitas profesional, dan akuntabilitas. Akuntabilitas sebagai kewajiban untuk memberikan pertanggungjawaban atas pengelolaan tersebut kepada pihak yang mempercayai kepadanya suatu tanggungjawab. Gregory (1995) sebagaimana yang dikutib oleh Jacobs (2000) menjelaskan bahwa akuntabilitas didefinisikan sebagai " the need to give an account of one's actions." Hal senada juga dijelaskan oleh Jones (1991).

Menurut Tim Studi Akuntansi Keuangan Pemerintah BPKP seperti yang dikutip Rosjidi (2001:144) makna akuntabilitas berarti perwujudan kewajiban untuk mempertanggungjawabkan keberhasilan atau kegagalan atas pelaksanaan misi organisasi dalam mencapai tujuan-tujuan dan sasaran-sasaran yang telah ditetapkan, melalui suatu media pertanggungjawaban secara periodik. Saleh dan Iqbal (1995) dalam Hartati (2008) juga berpendapat bahwa akuntabilitas merupakan sisi - sisi sikap dan watak kehidupan manusia. Akuntabilitas didefinisikan secara sempit sebagai kemampuan untuk memberikan jawaban kepada otoritas yang lebih tinggi atas tindakan "seseorang" atau "sekelompok orang" terhadap masyarakat secara luas atau dalam suatu organisasi. Dalam konteks instusi pemerintah, "seseorang" tersebut adalah pimpinan instansi pemerintah sebagai penerima amanat yang harus memberikan pertanggungjawaban atas pelaksanaan amanat tersebut kepada masyarakat atau publik sebagai amanat.

Pengertian lain dari akuntabilitas menurut Lawton dan Rose dapat dikatakan sebagai sebuah proses dimana seorang atau sekelompok orang yang diperlukan untuk membuat laporan aktivitas mereka dan dengan cara yang mereka sudah atau belum ketahui untuk melaksanakan pekerjaan mereka (YPAPI, 2004). Menurut Mardiasmo (2005) akuntabilitas publik adalah kewajiban pihak pemegang amanah (agent) untuk memberikan pertanggungjawaban, menyajikan, melaporkan dan mengungkapkan segala aktivitas dan kegiatan yang menjadi tanggungjawabnya kepada pihak pemberi amanah (principal) yang memiliki hak dan kewenangan untuk meminta pertanggungjawaban tersebut. Akuntabilitas (accountability) yaitu berfungsinya seluruh komponen penggerak jalannya kegiatan perusahaan, sesuai tugas dan kewenangannya masing-masing (Hartati, 2008).

\section{Akuntabilitas Keuangan}


Akuntabilitas keuangan merupakan pertanggungjawaban mengenai integritas keuangan, pengungkapan dan ketaatan terhadap peraturan perundangundangan. Sasarannya adalah laporan keuangan yang mencakup penerimaan, penyimpanan dan pengeluaran keuangan instansi pemerintah. Komponen pembentuk akuntabilitas keuangan terdiri atas :

\section{Organizational Citizenship Behavior (OCB)}

Organizational Citizenship Behavior (OCB) atau prilaku sosial organisasi seringkali disingkat dengan $O C B$, yaitu perilaku anggota organisasi. Konstruksi ini sangat terkenal dalam perilaku organisasi saat pertama kali diperkenalkan dengan dasar teori kepribadian dan sikap kerja. Organizational Citizenship Behavior (OCB) merupakan sikap ikut memiliki organisasi dan bertanggung jawab untuk memajukan dan memelihara kinerja organisasi melalui tindakan yang positif diluar peran formalnya sebagai karyawan. $O C B$ pertama kali diperkenalkan oleh Smith, Organ dan Near pada tahun 1983. Konsep ini sebenarnya serupa dengan konsep Katz dan Kahn (1964), bahwa perilaku organisasi yang paling mendasar untuk menfungsikan organisasi adalah inovatif dan spontaneouse, yang meliputi saling membantu yang lain, menjaga organisasi, memberikan ide yang bersifat membangun, pelatihan diri. dan penelitiannya yang lain (1978) tentang perilaku ekstra peran. Dickson (1964) juga menulis tentang sikap kerjasama dalam bukunya Management and the Worker, yang mana untuk menjadikan keseimbangan organisasi maka harus pro gerakan sosial.

Lebih lanjut Jones mengemukakan Organizational Citizenship Behavior (OCB) adalah perilaku informal yang mendukung efektivitas organisasi dan dilakukan secara sukarela. Organizational Citizenship Behavior (OCB) memiliki karakteristik yaitu perilaku yang dilakukan secara sukarela, perilaku yang dilakukan secara spontan, perilaku yang mendukung efektivitas organisasi, perilaku yang tidak mudah diambil dan dihargai melalui evaluasi kinerja terutama karena perilaku tersebut tidak tercantum dalam uraian jabatan.

\section{Dimensi Organizational Citizenship Behavior (OCB)}

Organ berpendapat bahwa perilaku citizenship atau ekstra peran ini diimplementasikan dalam 5 bentuk "perilaku,yaitu :

a. Altruism (perilaku membantu orang lain)

Sifat mementingkan kepentingan orang lain, seperti memberikan pertolongan pada kawan sekerja yang baru, dan menyediakan waktu untuk orang lain. Perilaku membantu rekan atau teman sekerja yang mengalami kesulitan dalam situasi yang sedang dihadapinya baik mengenai tugas dalam organisasi maupun masalah pribadi orang lain. Dimensi ini mengarah kepada memberi pertolongan yang bukan merupakan kewajiban yang ditanggungnya.

\section{b. Conscientiousness (ketelitian dan kehatihatian)}

Sifat kehati-hatian seperti efisiensi menggunakan waktu, dan tingkat kehadiran tinggi. Perilaku ini berusaha untuk melebihi yang diharapkan oleh perusahaan atau perilaku yang sukarela yang bukan merupakan kewajiban atau tugas karyawan. Dimensi ini menjangkau jauh diatas dan jauh kedepan dari panggilan tugas. Conscientiousness merupakan kontribusi terhadap efisiensi baik berdasarkan individu maupun kelompok.

\section{c. Sportsmanship (perilaku yang sportif)}

Sifat sportif dan positif, seperti menghindari komplain dan keluhan yang picik (Sportsmanship) adalah dengan memaksimalkan total jumlah waktu yang dipergunakan pada usaha-usaha yang konstruktif dalam organisasi. Perilaku yang memberikan toleransi 
terhadap keadaan yang kurang ideal dalam organisasi tanpa mengajukan keberatan-keberatan. Seseorang yang mempunyai tingkatan yang tinggi dalam sportsmanship akan menunjukkan sikap yang positif dan menghindar untuk melakukan komplain. Sportsmanship akan meningkatkan iklim yang positif diantara karyawan, karyawan akan lebih sopan dan bekerja sama dengan yang lain, sehingga akan menciptakan lingkungan kerja yang lebih menyenangkan.

\section{d. Courtesy (menjaga hubungan baik)}

Menjaga hubungan baik dengan rekan sekerjanya agar terhindar dari masalahmasalah interpersonal. Seseorang yang memiliki dimensi ini adalah orang yang menghargai dan memperhatikan orang lain. Sifat sopan dan taat, seperti melalui surat peringatan, atau pemberitahuan sebelumnya, dan meneruskan informasi dengan tepat. Courtesy dapat membantu mencegah timbulnya masalah dan memaksimalkan penggunaan waktu.

\section{e. Civic virtue (kebijaksanaan warga)}

Perilaku yang mengindikasikan tanggung jawab pada kehidupan organisasi (mengikuti perubahan dalam organisasi, mengambil inisiatif untuk merekomendasikan bagaimana operasi atau prosedur-prosedur organisasi dapat diperbaiki, dan melindungi sumber- sumber yang dimiliki oleh organisasi). Dimensi ini mengarah kepada tanggung jawab yang diberikan organisasi kepada seseorang untuk meningkatkan kualitas bidang pekerjaan yang ditekuninya. Sifat bijaksanan atau keanggotaan yang baik, seperti melayani komite atau panitia, melakukan fungsi-fungsi sekalipun tidak diwajibkan untuk membantu memberikan kesan baik bagi organisasi. Civic Virtue dapat memberikan pelayanan yang diperlukan bagi kepentingan organisasi”.

\section{Penelitian Terdahulu}

Di Indonesia penelitian mengenai akuntabilitas disektor publik masih sangat kurang. Teclock dan Kim (1987) dalam Hartati (2008) meneliti pengaruh akuntabilitas terhadap proses kognitif seseorang. Hasil penelitiannya membuktikan bahwa subjek yang diberikan instruksi diawal (postexposure accountability) bahwa pekerjaan mereka akan diperiksa oleh atasan, melakukan proses kognitif yang lebih lengkap, memberikan respon yang lebih tepat dan melaporkan keputusan yang lebih realistis. Sejalan dengan penelitian Teclock dan Kim (1987), Meissier dan Quilliam (1992) juga meneliti pengaruh akuntabilitas terhadap proses kognitif seseorang dalam bekerja.

Hasil penelitiannya membuktikan bahwa subjek dengan akuntabilitas tinggi melakukan proses kognitif yang lebih lengkap. Cloyd (1997) meneliti pengaruh akuntabilitas terhadap kualitas hasil kerja auditor. Hasil penelitian Cloyd (1997) membuktikan akuntabilitas dapat meningkatkan kualitas hasil kerjaa uditor jika pengetahuan audit yang dimiliki tinggi. Asumsi yang digunakan dalam penelitian ini adalah bahwa kompleksitas pekerjaan yang dihadapi tinggi. Penelitian Cloyd (1997) ini di kembangkan oleh Tan dan Alison (1999) dengan menilai kualitas hasil kerja berdasarkan kompleksitas kerja yang dihadapi. Seseorang dengan akuntabilitas tinggi memiliki keyakinan yang lebih tinggi bahawa pekerjaan mereka akan diperiksa oleh pimpinan dibandingkan dengan seseorang yang memiliki akuntabilitas rendah. Hasil penelitian Tan dan Alison (1999) ini tidak konsisten dengan Cloyd (1997). Tan dan Alison (1999)membuktikan bahwa akuntabilitas tidak mempengaruhi kualitas hasil kerja baik untuk pekerjaan dengan kompleksitas kerja rendah, menengah ataupun tinggi.

Penelitian empiris tentang pelaporan akuntabilitas di Indonesia juga dilakukan oleh Ahmad Solikin tahun 2005. Penelitian ini bertujuan untuk menilai apakah dalam melaporkan laporan akuntabilitas (kinerja) di departemen-departemen di Indonesia 
terdapat pernyataan yang melebih-lebihkan hasil kinerja mereka. Objek penelitian ini adalah tiga puluh dua departemen kementrian yang ada di Indonesia yang melaporkan laporan akuntabilitas pada tahun 2002. Penelitian ini menggunakan contentanalisys untuk mengukur kualitas laporan akuntabilitas tersebut. Hasil dari penelitian ini menunjukkan bahwa kebanyakan unit organisasi cenderung untuk melaporkan kinerja mereka secara tinggi. Hal ini berarti bahwa kebanyakan unit organisasi menjunjung dirinya sendiri untuk kinerja yang baik dan menyalahkan faktor luar jika terjadi kegagalan dalam kinerja mereka.

Riketta dan Landererer (2002) juga mengungkapkan bahwa komitmen organisasi dapat digunakan untuk mengidentifikasi kinerja karyawan. Penelitian ini memperluas penelitian Riketta dan landerrer (2002) yang meneliti pengaruh komitmen organisasi terhadap perilaku kerja dengan akuntabilitas sebagai variabel pemoderasi. Hasil penelitian Riketta dan Lenderrer (2002) justru menyatakan bahwa akuntabilitas bukan sebagai variabel pemoderasi, tetapi sebagai variabel yang independen. Akuntabilitas sebagai variabel pemoderasi dalam penelitian Riketta dan landerer (2002) tidak terdukung. Penelitian Mahmudah dan Mapuasari (2013) menemukan bahwa akuntabilitas bukan sebagai variabel pemoderasi tetapi sebagai variabel intervening. Jadi dalam penelitian ini akuntabilitas memediasi hubungan antara komitmen organisasi dan organization citizenship behavior.

\section{Pengembangan Hipotesis}

\section{Gaya Kepemimpinan terhadap Organizational Citizenship Behavior}

Kepemimpinan adalah kemampuan untuk mempengaruhi orang lain untuk mencapai tujuan dengan antusias (David, Keith, 1985). Kemampuan untuk memimpin orang lain adalah sebuah kualitas fundamental yang dicari organisasi - organisasi dalam pengorganisasian pegawai. Para pemimpin yang efektif mengandalkan daya tarik emosional untuk membantu menyampaikan visi - misi organisasi dan pencapaian tujuan organisasi, terlebih Institusi militer sangat kental akan budaya komando dalam pelaksanaan kinerjanya, maka para pegawai cenderung berperilaku OCB dipengaruhi oleh tipe kepemimpinan para atasan atau pemimpin mereka.

Adanya dukungan dari atasan juga turut mempengaruhi OCB. Dukungan yang diberikan oleh pemimpin dapat memunculkan sikap positif terhadap pekerjaan dan organisasi, serta mempunyai keinginan untuk membantu rekan sekerjanya dan akan lebih kooperatif (Organ, Padsakoff ,2006:253). Barbuta dan Schol (1999) menemukan bahwa yang dapat mempengaruhi OCB adalah perilaku kepemimpinan, dengan korelasi yang sangat kuat.

H1: Gaya kepemimpinan berpengaruh terhadap organizational citizenship behavior

\section{Komitmen Organisasi terhadap Organizational Citizenship Behavior}

Faktor lain yang turut mempengaruhi Organizational Citizenship Behavior $(O C B)$ adalah komitmen organisasi. Karyawan yang memiliki komitmen terhadap organisasi akan merasa bahagia menjadi bagian dari organisasi tersebut, mempunyai kepercayaan dan perasaan yang baik terhadap organisasinya,dan mempunyai keinginan untuk tetap tinggal dalam organiasasi, serta bermaksud untuk melakukan apa yang terbaik bagi organisasi sehingga akan lebih memunculkan $O C B$. Riketta dan Landerrer (2002) menemukan bahwa komitmen organisasi berpengaruh positif terhadap perilaku kerja dalam hal ini $O C B$. Individu yang mempunyai komitmen organisasi afektif yang 
tinggi akan memiliki niat untuk membalas (reciprocate) untuk organisasi melalui melibatkan diri dalam $O C B$ (Cropanzano et al., 2003).

Lingkungan kerja yang menyuburkan komitmen organisasi akan berkontribusi dengan peningkatan kualitas kerja. Cara anggota TNI melihat lingkungan kerja dapat mempengaruhi kinerja dan lingkungan kerja juga memainkan peran kunci dalam mengembangkan sikap dan perilaku pekerjaan. Menyadari akan pentingnya komitmen organisasi, pemerintah di tahun

2011 mulai memberikan remunerasi yang berupa tunjangan jabatan untuk meningkatkan kesejahteraan anggota TNI, sehingga diharapkan komitmen organisasi semakin tinggi.

H2: komitmen organisasi berpengaruh terhadap organizational citizenship behavior.

\section{Akuntabilitas terhadap Organizational Citizenship Behavior}

March dan Olsen (1989) dalam Moynihan dan pandey (2007) mengamati bahwa harapan, preferensi, pengalaman, dan interpretasi dari tindakan orang lain semua dibangun dalam institusi. Orang membangun keyakinan dan perilaku berdasarkan apa yang dilihat dan tepat dalam lingkungan mereka dan norma-norma perilaku orang-orang di sekitar mereka. Akuntabilitas melibatkan harapan atau asumsi bahwa individu akan berperilaku dengan cara tertentu (Hall, et al 2004). Jelas bahwa perilaku karyawan mempunyai hubungan dengan akuntabilitas. Kepercayaan dan akuntabilitas tertanam dalam konteks sosial yang berhubungan dengan variabel sosial-psikologis dalam konteks organisasi baik formal maupun informal (Ammeter et al 2004 dalam Hall, et al 2004). Menurut Budiyanto (2013) untuk menciptakan efektifitas organisasi yang berdampak pada peningkatan produktifitas, perlu menciptakan suasana kerja yang memberi peluang munculnya perilaku $O C B$ dikalangan pegawai. $\mathrm{Di}$ instansi militer, tuntutan akuntabilitas internal sangat tinggi. Akuntabilitas internal ini diduga dapat menjadi pemicu anggota berperilaku $O C B$. Dari sisi akuntabilitas eksternal, dunia militer tidak lagi ekslusif dan tertutup seperti pada era orde baru. Publik menyaksikan dan turut mengawasi kinerja TNI dalam menjalankan tugasnya. Oleh sebab itu, kesadaran anggota TNI akan akuntabilitas eksternal yang harus dipenuhi akan mampu meningkatkan semangat untuk berperilaku $O C B$.

H3: akuntabilitas berpengaruh terhadap organizational citizenship behavior

\section{METODE PENELITIAN}

\section{Jenis Penelitian}

Jenis penilitian ini merupakan penelitian lapangan dengan menggunakan metode survei melalui penyebaran kuesioner. Disain penelitian yang digunakan dalam penelitian ini bersifat penjelasan (explanatory research) yaitu menjelaskan hubungan kausalitas antara variabel eksogen dan variabel endogen. Populasi adalah sekelompok orang, kejadian atau segala sesuatu yang mempunyai karakteristik tertentu (Indriantoro dan Supomo, 2002). Populasi dari penelitian ini adalah pegawai atau anggota TNI-AD di Kota Bengkulu.

Sampel dalam penelitian ini adalah beberapa orang anggota TNI-AD yang bertugas di Korem 041/Gamas, Kodim 0407 dan Kompi Senapan B/JY kota Bengkulu. Pengambilan sampel mengikuti teori pengambilan sampel secara nonprobabilistik dengan menggunakan metode purposive sampling. Purposive sampling (judgment sampling) yaitu pengambilan sampel dari suatu populasi dengan pertimbangan kriteria tertentu (Jogiyanto, 2007), dalam hal ini kriteria tersebut adalah pegawai atau anggota TNI-AD yang memiliki masa kerja minimal 2 tahun. Dasar pertimbangannya adalah diperkirakan dalam jangka waktu 2 tahun pegawai memiliki waktu dan pengalaman untuk beradaptasi serta menilai sendiri kondisi lingkungan kerjanya, sehingga mampu 
mengidentifikasi dan menentukan jawaban yang sesuai pada pertanyaan dalam kuesioner yang terkait dengan variabel penelitian. Jumlah Sampel dengan kriteria tersebut berdasarkan data Korem 041/Gamas terdapat 170 sampel yang ada di kota Bengkulu.

\section{Definisi Operasional dan Pengukuran Variabel}

Variabel dalam penelitian ini terdiri dari variabel eksogen dan endogen. Variabel eksogen adalah variabel yang tidak diprediksi oleh variabel lain dalam model (Ferdinand,

2006). Variabel eksogen dalam penelitian ini adalah organizational citizenship behavior $(O C B)$. Variabel endogen adalah variabel yang diprediksikan oleh satu atau beberapa variabel lain (Ferdinand, 2006). Variabel endogen dalam penelitian ini adalah gaya kepemimpinan, komitmen organisasi dan akuntabilitas.

Ada empat variabel yang digunakan dalam penelitian ini dan diukur dengan menggunakan instrumen-instrumen yang diadopsi dari literatur-literatur yang digunakan dalam penelitian terdahulu. Konstruk tersebut adalah:

\section{Organization Citizenship Behaviour (OCB)}

$O C B$ adalah perilaku karyawan yang melebihi peran yang diwajibkan, yang secara tidak langsung diakui secara eksplisit oleh sistem reward formal (Organ,1988 dalam Bolino, et al 2002). $O C B$ diukur dengan 4 item dari dimensi arah langsung ke organisasi dan 4 dimensi arah langsung ke individu (William dan Anderson, 1991). Pengukuran ini konsisten dengan Chen dan Yang (2012), Rayner et al (2012). Penilaian responden terhadap indikator tersebut diukur dengan 5 skala likert dari sangat tidak setuju sampai sangat setuju, yaitu 1 berarti sangat tidak setuju (STS), 2 berarti tidak setuju (TS), 3 berarti kurang setuju (KS), 4 berarti setuju (S) dan 5 berarti sangat setuju (SS). Semakin tinggi skor variabel ini berarti $O C B$ pada organisasi tersebut semakin baik. Sebaliknya, semakin rendah skor ini berarti $O C B$ pada organisasi tersebut rendah.

\section{Gaya Kepemimpinan}

Gaya kepemimpinan menurut Davis, Keith. (1985) adalah pola tindakan pemimpin secara keseluruhan seperti yang dipersepsikan oleh para pegawainya. Gaya kepemimpinan mewakili filsafat, ketrampilan, dan sikap pemimpin dalam politik. Behling, Orlando dan James M. McFillen (1996) dalam Fuad Mas'ud (2004) mengembangkan kuesioner gaya kepemimpinan transformasional.

Kuesioner ini terdiri dari dua macam, indikatornya adalah sebagai berikut :

\section{Kuesioner Kepercayaan Pengikut (Follower Belief}

Questionnaire) (1) Inspirasi

(2) Kekaguman

(3) Pemberdayaaan

2. Kuesioner Atribut Perilaku Pemimpin (Attributes of Leader Behavior

Questionnaire) (1) Menunjukkan empati

(2) Menjelaskan misi dengan menarik

(3) Menunjukkan keyakinan

(4) meningkatkan image

(5) memberikan peluang untuk sukses

Penilaian responden terhadap indikator tersebut diukur dengan 5 skala Likert dari sangat tidak setuju sampai sangat setuju, yaitu 1 berarti sangat tidak setuju (STS), 2 
berarti tidak setuju (TS), 3 berarti kurang setuju (KS), 4 berarti setuju (S) dan 5 berarti sangat setuju (SS).

\section{Komitmen organisasi}

Konsep komitmen adalah tingkat sampai mana seseorang karyawan/pegawai memihak sebuah organisasi serta tujuan - tujuan dan keinginan untuk mempertahankan keanggotaannya dalam organisasi tersebut (Stephen P. Robbins dan Timothy A. J: 100). Komitmen organisasi diukur dari 1 faktor/dimensi yaitu afektif dengan 4 item versi Meyer dan Allen (1997) konsisten dengan penelitian Fry,et al (2011), Riketta dan Landerer (2002). Penilaian responden terhadap indikator tersebut diukur dengan 5 skala Likert dari sangat tidak setuju sampai sangat setuju, yaitu 1 berarti sangat tidak setuju (STS), 2 berarti tidak setuju (TS), 3 berarti kurang setuju (KS), 4 berarti setuju (S) dan 5 berarti sangat setuju (SS). Semakin tinggi skor variabel ini berarti komitmen dari anggota TNI tersebut terhadap organisasi semakin baik. Sebaliknya, semakin rendah skor ini berarti komitmen dari anggota TNI tersebut rendah terhadap Organisasi.

\section{Akuntabilitas}

Akuntabilitas eksternal adalah akuntabilitas dari entitas pemerintah lokal untuk pemangku kepentingan seperti pemerintah pusat, DPRD, dan masyarakat (Akbar,2012). Akuntabilitas eksternal diukur dengan 5 item konsisten dengan Riketta dan landerer (2002). Akuntabilitas internal terkait hubungan antara atasan dan bawahan dalam organisasi (Stewart dan Walsh, 1994 dalam Akbar, 2012). akuntabilitas internal diukur dengan 2 item sama dengan Akbar (2012). Penilaian responden terhadap indikator tersebut diukur dengan 5 skala Likert dari sangat tidak setuju sampai sangat setuju, yaitu 1 berarti sangat tidak setuju (STS),

2 berarti tidak setuju (TS), 3 berarti kurang setuju (KS), 4 berarti setuju (S), 5 berarti sangat setuju (SS). Semakin tinggi skor variabel ini berarti akuntabilitas dari anggota TNI tersebut semakin baik. Sebaliknya, semakin rendah skor ini berarti akuntabilitas dari anggota TNI tersebut semakin rendah atau tidak dijalankannya praktik akuntabilitas oleh anggota TNI tersebut.

\section{Metode Pengumpulan Data}

Karena data yang diperlukan berupa opini individu maka teknik pengumpulan data dalam penelitian ini berupa survei. Survei merupakan proses pengukuran yang digunakan untuk mengumpulkan informasi dalam sebuah wawancara yang terstruktur dengan baik dengan atau tanpa seorang pewawancara (Cooper dan Schindler, 2011:242). Alat pengumpulan data menggunakan survei kuesioner yang berisi pertanyaan untuk responden. Kuesioner diantar langsung ke kantor angkatan darat kota Bengkulu.

\section{Metode Analisis}

Dalam penelitian ini analisis data menggunakan pendekatan Partial Least Square (PLS). PLS adalah model persamaan Structural Equation Modeling (SEM) yang berbasis komponen atau varian. Menurut Ghozali (2006), PLS merupakan pendekatan alternatif yang bergeser dari pendekatan SEM berbasis kovarian menjadi berbasis varian.

SEM yang berbasis kovarian umumnya menguji kausalitas atau teori sedangkan PLS lebih bersifat predictive model. PLS merupakan metode analisis yang powerfull (Ghozali,2006), karena tidak didasarkan pada banyak asumsi. Misalnya, data harus terdistribusi normal, sampel tidak harus besar. Selain dapat digunakan untuk mengkonfirmasi teori, PLS dapat digunakan untuk menjelaskan ada tidak hubungan antar 
variabel laten. PLS dapat sekaligus menganalisis konstruk yang dibentuk dengan indikator reflektifbdan formatif.

\section{Statistik Deskriptif}

Dalam penelitian ini digunakan statistik deskriptif untuk memberikan gambaran mengenai demografi responden penelitian dan deskriptif mengenai variabel-variabel penelitian untuk mengetahui distribusi frekuensi absolut yang menunjukkan angka rata-rata (mean) kisaran aktual, kisaran teoritis, penyimpangan baku (standard deviation), dan kecenderungan jawaban responden.

\section{Model Pengukuran atau Outer Model}

Convergent validity dari model pengukuran dengan model reflektif indikator dinilai berdasarkan skor AVE dan communality masing-masing harus bernilai diatas 0,5. Artinya, probabilitas indikator disuatu konstruk masuk ke variabel lain lebih rendah $50 \%$ sehingga probabilitas indikator tersebut konvergen dan masuk di konstruk yang dimaksud lebih besar, yaitu diatas 50\%, (Jogiyanto dan Willy, 2009). Korelasi antar item skor/komponen skor dengan konstruk skor yang dihitung dengan PLS. Ukuran reflektif dikatakan tinggi jika berkorelasi lebih dari 0,70 dengan konstruk yang ingin diukur. Namun demikian untuk penelitian tahap awal dari pengembangan skala pengukuran nilai loading 0,5 sampai 0,60 dianggap cukup (Chin, 1998 dalam Ghozali, 2000). Discriminant validity dari model pengukuran dengan reflektif indikator dinilai berdasarkan cross loading pengukuran dengan konstruk. Jika korelasi konstruk dengan item pengukuran lebih besar daripada ukuran konstruk lainnya, maka akan menunjukkan bahwakonstruk laten memprediksi ukuran pada blok yang lebih baik daripada ukuran blok lainnya. Uji reliabilitas dapat dilihat dari nilai cronbach's alpha dan nilai composite reliability. Untuk dapat dikatakan suatu konstruk reliabel, maka nilai cronbach's alpha harus > 0,6 dan nilai composite reliability harus 0,7 (Jogiyanto dan Willy, 2009).

\section{Model Struktural atau Inner Model}

Inner model (inner relation, structural model dan substantive theory) menggambarkan hubungan antar variabel laten berdasarkan pada teori substantif. Model struktural dievaluasi dengan menggunakan $R$-square untuk konstruk dependen, StoneGeisser Q-square test untuk predictive relevance dan uji t serta signifikansi dari koefisien parameter jalur struktural.

Dalam menilai model dengan PLS dimulai dengan melihat $R$-square untuk setiap variabel laten dependen. Interprestasinya sama dengan interpretasi pada regresi. Perubahan $R$ - square dapat digunakan untuk menilai pengaruh variabel laten independen tertentu terhadap variabel laten dependen apakah mempunyai pengaruh yang substantif (Ghozali, 2006). Disamping melihat nilai $R$-square, model PLS juga dievaluasi dengan melihat nilai koefisien path atau inner model dimana menunjukkan tingkat signifikansi dalam pengujian hipotesis. Skor koefisien path atau inner model yang ditunjukkan oleh nilai t-statistic, harus diatas 1,96 untuk pengujian alpha 5\% (Hair et al, 2006) dalam Jogiyanto dan Willy (2009).

\section{HASIL DAN PEMBAHASAN}

\section{Deskripsi Objek Penelitian}

Populasi dalam penelitian ini adalah seluruh anggota atau pegawai sipil maupun militer di Institusi militer Kota Bengkulu. Sedangkan Sampel dalam penelitian ini adalah 170 orang anggota TNI-AD yang bertugas di Korem 041/Gamas, Kodim 0401 
dan Kompi Senapan B/JY kota Bengkulu. Instrumen yang digunakan dalam penelitian ini berupa kuesioner yang diberikan secara langsung kepada responden disetiap institusi yang menjadi tempat penelitian. Kuesioner diedarkan dari tanggal 4 Juni -18 Juni 2014. Total kuesioner yang disebarkan dalam penelitian ini berjumlah 170 kuesioner. Dari 170 (100\%) kuesioner yang disebarkan, 170 (100\%) kuesioner diterima kembali. Dari $170(100 \%)$ yang diterima, 170 (100\%) dapat diolah.

Adapun profil responden yang berpartisipasi dalam penelitian ini ditunjukkan pada tabel 4.1 sebagai berikut:

\begin{tabular}{l|c|c}
\multicolumn{3}{c}{$\begin{array}{c}\text { Tabel 4.1 } \\
\text { Sampel }\end{array}$} \\
\hline \multicolumn{1}{c}{ Uraian } & Frekuensi & Persentase \\
\hline Jenis Kelamin: & 156 & $91,76 \%$ \\
Pria & 14 & $8,24 \%$ \\
Wanita & $\mathbf{1 7 0}$ & $\mathbf{1 0 0 \%}$ \\
\hline Total & & \\
\hline Usia: & 34 & $20,00 \%$ \\
20-25 tahun & 51 & $30,00 \%$ \\
26-30 tahun & 83 & $48,82 \%$ \\
31-35 tahun & 2 & $1,18 \%$ \\
>35 tahun & $\mathbf{1 7 0}$ & $\mathbf{1 0 0 \%}$ \\
\hline Total & & \\
\hline Tingkat pendidikan & 125 & $69,44 \%$ \\
SMA & 18 & $12,59 \%$ \\
D3 & 25 & $16,70 \%$ \\
S1 & 2 & $1,27 \%$ \\
S2 & $\mathbf{1 7 0}$ & $\mathbf{1 0 0 \%}$ \\
\hline Total & & \\
\hline Masa Kerja & 35 & $20,69 \%$ \\
$<$ 5 tahun & 65 & $38,23 \%$ \\
5-10 tahun & 15 & $8,43 \%$ \\
11-15 tahun & 28 & $16,67 \%$ \\
16-20 tahun & 27 & $15,98 \%$ \\
\hline 20 tahun & $\mathbf{1 7 0}$ & $\mathbf{1 0 0 \%}$ \\
\hline Total & & \\
\hline Sumber: Data primer diolah, 2014 & \\
\hline
\end{tabular}

Dari tabel 4.1 dapat dilihat gambaran tentang jenis kelamin, tingkat pendidikan, dan masa kerja responden. Jika dilihat dari jenis kelamin responden pria lebih banyak dari wanita yaitu pria 156 orang $(91,76 \%)$. Dari tingkat pendidikan, mayoritas para pegawai tamatan SMA, yaitu sebanyak 125 orang $(69,44 \%)$. Dari sisi masa kerja, sebagian besar responden memiliki masa kerja lebih dari 5-10 tahun yaitu sebanyak 65 orang $(38,23 \%)$. Hal ini menunjukkan bahwa responden sudah memiliki cukup berpengalaman karena mereka telah ikut serta dalam organisasi tersebut cukup lama yaitu antara 5 sampai 10 tahun, sehingga responden telah mengetahui dengan baik untuk kondisi dan lingkungan organisasi.

\section{Analisis Statistik Dekriptif}


Data yang telah terkumpul dari kuesioner yang telah disebarkan ditabulasi dengan tujuan sebagai alat analisis data. Hasil tabulasi tersebut diolah menggunakan program SPPS versi 16.0 yang menghasilkan deskripsi statistik variabel penelitian, seperti yang tampak pada tabel 4.2 berikut:

Tabel 4.2

\section{Deskripsi Statistik Responden}

\begin{tabular}{l|c|c|c|c|c|c}
\hline \multicolumn{1}{c|}{ Variabel } & $\mathrm{N}$ & $\begin{array}{c}\text { Kisaran } \\
\text { Teoritis }\end{array}$ & $\begin{array}{c}\text { Rata- } \\
\text { rata } \\
\text { Teoritis }\end{array}$ & $\begin{array}{c}\text { Kisaran } \\
\text { Aktual }\end{array}$ & $\begin{array}{c}\text { Rata- } \\
\text { rata } \\
\text { Aktual }\end{array}$ & $\begin{array}{c}\text { Std. } \\
\text { Deviasi }\end{array}$ \\
\hline OCB (Y) & 170 & $8-40$ & 24 & $30-37$ & 33,45 & 1,414 \\
\hline Gaya Kepemimpinan(X1) & 170 & $8-40$ & 24 & $30-40$ & 33,54 & 2,277 \\
\hline Komitmen Organisasi (X2) & 170 & $4-20$ & 12 & $13-20$ & 16,95 & 1,215 \\
\hline Akuntabilitas (X3) & 170 & $7-35$ & 21 & $27-33$ & 29,58 & 1,462 \\
\hline
\end{tabular}

Sumber: Data primer diolah, 2014

Berdasarkan tabel 4.2 di atas, variabel $O C B$ mempunyai bobot kisaran teoritis sebesar 8 sampai dengan 40 dengan nilai rata-rata sebesar 24 sedangkan pada kisaran aktualnya, variabel $O C B$ mempunyai bobot kisaran sesungguhnya sebesar 30 sampai dengan 37 dengan nilai rata-rata sebesar 33,45 dan standar deviasi sebesar 1,414 nilai ratarata jawaban variabel $O C B$ untuk kisaran aktualnya di atas nilai rata-rata kisaran teoritis, mengindikasikan bahwa penilaian responden terhadap aspek $O C B$ dengan 4 item dari dimensi arah langsung ke organisasi dan 4 dimensi arah langsung ke individu adalah tinggi. Berdasarkan lampiran 1 menunjukkan bahwa jawaban responden untuk konstruk gaya kepemimpinan cenderung homogen.

Variabel gaya kepemimpinan mempunyai bobot kisaran teoritis sebesar 8 sampai dengan 40 dengan nilai rata-rata sebesar 24 sedangkan pada kisaran aktualnya, variabel gaya kepemimpinan mempunyai bobot kisaran aktualnya sebesar 30 sampai 40 dengan nilai rata- rata sebesar 33,54 dan standar deviasi sebesar 2,277 nilai rata-rata jawaban variabel gaya kepemimpinan untuk kisaran aktualnya di atas nilai rata-rata kisaran teoritis, mengindikasikan bahwa para responden menilai gaya kepemimpinan pada institusi mereka sudah berjalan cukup baik. Berdasarkan lampiran 1 menunjukkan bahwa jawaban responden untuk konstruk gaya kepemimpinan cenderung homogen.

Variabel komitmen organisasi mempunyai bobot kisaran teoritis sebesar 4 sampai dengan 20 dengan nilai rata-rata sebesar 12 sedangkan pada kisaran aktualnya, variabel komitmen organisasi mempunyai bobot kisaran aktualnya sebesar 13 sampai 20 dengan nilai rata-rata sebesar 16,95 dan standar deviasi sebesar 1,215 nilai rata-rata jawaban variabel komitmen organisasi untuk kisaran aktualnya di atas nilai rata-rata kisaran teoritis, mengindikasikan bahwa para responden menilai komitmen organisasi yang dimiliki anggota TNI-AD pada institusi mereka sudah berjalan cukup baik. Berdasarkan lampiran 1 menunjukkan bahwa jawaban responden untuk konstruk komitmen organisasi cenderung homogen.

Variabel akuntabilitas mempunyai bobot kisaran teoritis sebesar 7 sampai dengan 35 dengan nilai rata-rata sebesar 21 sedangkan pada kisaran aktualnya, variabel akuntabilitas mempunyai bobot kisaran aktualnya sebesar 27 sampai 33 dengan nilai rata-rata sebesar 29,58 dan standar deviasi sebesar 1,462 nilai rata-rata jawaban variabel akuntabilitas untuk kisaran aktualnya di atas nilai rata-rata kisaran teoritis, mengindikasikan bahwa para responden menilai praktik akuntabilitas pada institusi mereka sudah berjalan cukup baik. 
Berdasarkan lampiran 1 menunjukkan bahwa jawaban responden untuk konstruk akuntabilitas cenderung homogen.

\section{Analisis Data}

\section{Evaluasi Measurement (Outer) Model}

Adapun model pengukuran untuk uji validitas dan reabilitas, koefisien determinasi model dan koefisien jalur untuk model persamaan, dapat dilihat pada gambar 4.1 berikut:

\section{Gambar 4.1}

\section{Tampilan Hasil PLS Algorithm}

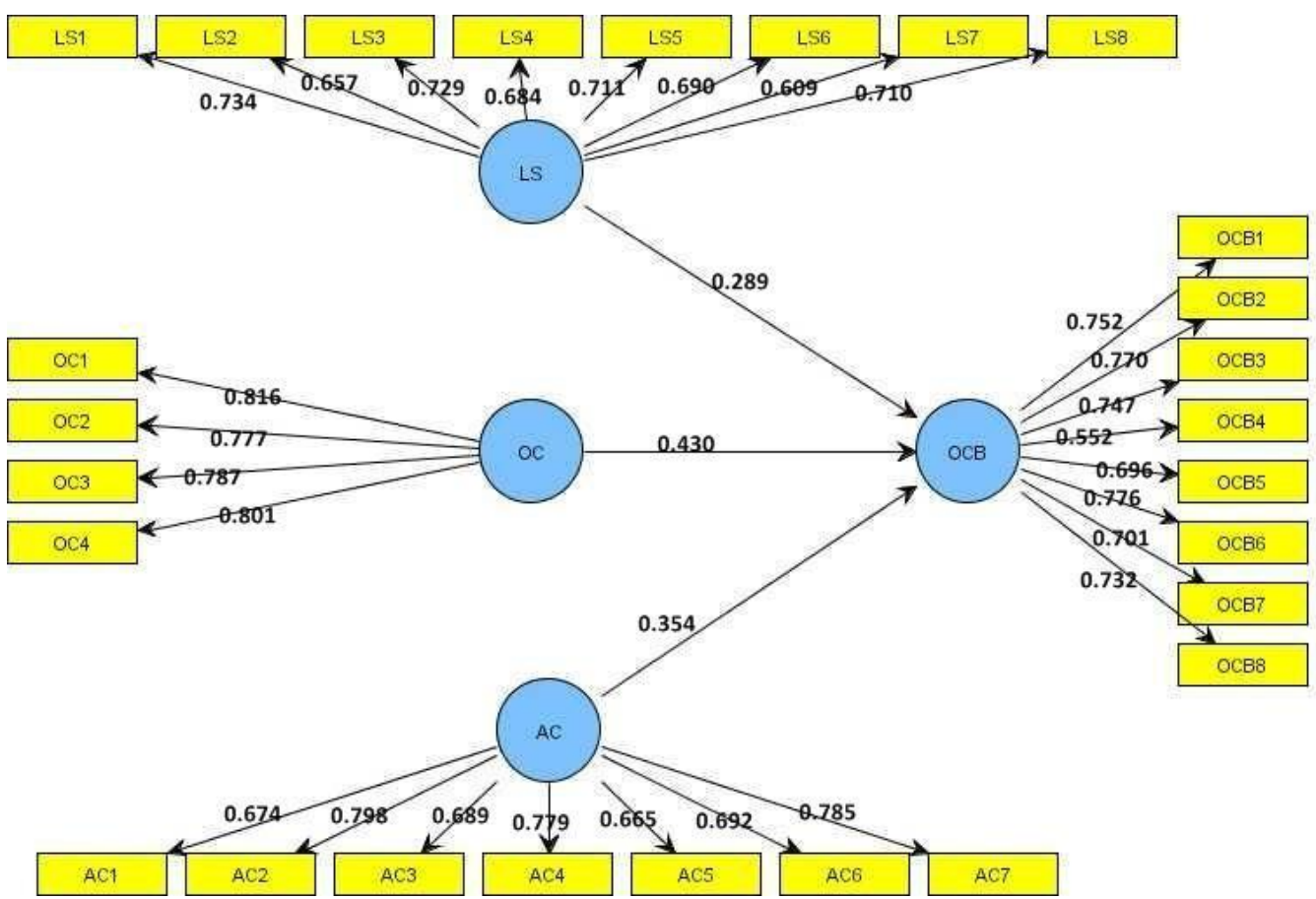

Gambar 4.1 tampilan output model pengukuran, 2014

\section{Convergent Validity}

Tabel 4.3

AVE dan communality

\begin{tabular}{l|c|c}
\hline & AVE & Communality \\
\hline LS & 0,6939 & 0,6939 \\
\hline OC & 0,6302 & 0,6302 \\
\hline AC & 0,5188 & 0,5188 \\
\hline OCB & 0,5066 & 0,5066 \\
\hline
\end{tabular}

Sumber: Pengolahan data dengan PLS, 2014

Validitas konvergen dari model pengukuran dengan menggunakan indikator reflektif dinilai berdasarkan loading factor indikator-indikator yang mengukur konstruk tersebut. Dalam penelitian ini terdapat 4 konstruk dengan jumlah indikator antara 4 sampai dengan 8 indikator dengan skala 1 sampai 5. Berdasarkan hasil faktor loading diatas maka dapat disimpulkan bahwa konstruk mempunyai convergent validity yang baik. 


\section{Discriminate Validity}

Pengujian discriminant validity dilakukan untuk membuktikan apakah indikator pada suatu konstruk akan mempunyai loading factor terbesar pada konstruk yang dibentuknya dari pada loading factor dengan konstruk yang lain. Dapat di lihat cross loading pada tabel 4.4 berikut:

Tabel 4.4

Cross Loading

\begin{tabular}{|c|c|c|c|c|}
\hline & $\mathrm{AC}$ & $\mathrm{LS}$ & $\mathrm{OC}$ & OCB \\
\hline AC1 & 0,6743 & 0,3902 & 0,3167 & 0,3472 \\
\hline $\mathrm{AC2}$ & 0,7978 & 0,3793 & 0,3762 & 0,4051 \\
\hline $\mathrm{AC3}$ & 0,6894 & 0,3404 & 0,3562 & 0,3891 \\
\hline AC4 & 0,7798 & 0,3216 & 0,3563 & 0,4501 \\
\hline AC5 & 0,6658 & 0,3561 & 0,3156 & 0,4062 \\
\hline AC6 & 0,6926 & 0,3701 & 0,3235 & 0,3573 \\
\hline AC7 & 0,7854 & 0,3807 & 0,3268 & 0,4021 \\
\hline LS1 & 0,3432 & 0,7342 & 0,4012 & 0,4309 \\
\hline LS2 & 0,3238 & 0,6570 & 0,4103 & 0,4103 \\
\hline LS3 & 0,3901 & 0,7292 & 0,4029 & 0,4004 \\
\hline LS4 & 0,3801 & 0,6842 & 0,3901 & 0,3907 \\
\hline LS5 & 0,3756 & 0,7113 & 0,3978 & 0,3078 \\
\hline LS6 & 0,3321 & 0,6904 & 0,4030 & 0,4332 \\
\hline LS7 & 0,3907 & 0,6093 & 0,4005 & 0,3885 \\
\hline LS8 & 0,3177 & 0,7106 & 0,3982 & 0,4112 \\
\hline OC1 & 0,3694 & 0,3309 & 0,8164 & 0,4860 \\
\hline OC2 & 0,3077 & 0,3408 & $\mathbf{0 , 7 7 7 1}$ & 0,4721 \\
\hline OC3 & 0,3197 & 0,3122 & 0,7876 & 0,4182 \\
\hline OC4 & 0,3602 & 0,3224 & $\mathbf{0 , 8 0 1 2}$ & 0,4651 \\
\hline OCB1 & 0,2750 & 0,3507 & 0,4381 & 0,7522 \\
\hline OCB2 & 0,5465 & 0,5465 & 0,3970 & 0,7704 \\
\hline OCB3 & 0,5447 & 0,5034 & 0,3759 & 0,7470 \\
\hline OCB4 & 0,4653 & 0,4122 & 0,2534 & 0,5529 \\
\hline OCB5 & 0,2980 & 0,3012 & 0,4068 & 0,6969 \\
\hline OCB6 & 0,4103 & 0,3908 & 0,3968 & 0,7765 \\
\hline OCB7 & 0,3568 & 0,3791 & 0,5595 & 0,7016 \\
\hline OCB8 & 0,2803 & 0,7560 & 0,4166 & 0,7326 \\
\hline
\end{tabular}

Berdasarkan tabel 4.4 di atas, menunjukkan nilai cross loading juga menunjukkan adanya discriminate validity yang baik oleh karena nilai korelasi indikator terhadap konstruknya lebih tinggi dibandingkan nilai kolerasi indikator dengan konstruk lainnya. Sebagai ilustrasi loading factor LS1 (indikator pertanyaan untuk gaya kepemimpinan) adalah sebesar 0,6743 yang lebih tinggi daripada loading factor dengan konstruk lain, yaitu LS (0,3902), OC (0,3167) dan OCB (0,3472).

Tabel tersebut juga menunjukkan bahwa indikator-indikator komitmen organisasi juga mempunyai nilai loading factor yang lebih tinggi daripada loading factor dengan konstruk yang lain. Hal serupa juga tampak pada indikator akuntabilitas Dengan demikian, 
konstruk laten memprediksi indikator pada blok mereka lebih baik dibandingkan dengan indikator di blok yang lain.

\section{Composite Reliability dan Cronbach's Alpha}

Disamping uji validitas konstruk, dilakukan juga uji reliabilitas konstruk yang diukur dengan composite reliability dan cronbach's alpha dari blok indikator yang mengukur konstruk. Berikut ini adalah hasil pengujian composite reliability dan cronbach's alpha dari Smart PLS:

Tabel 4.5

Composite Reliability dan Cronbach's Alpha

\begin{tabular}{l|c|c}
\hline \multicolumn{1}{c|}{ Construct } & Composite Reliability & Cronbach Alpha \\
\hline LS & 0,9188 & 0,9675 \\
\hline OC & 0,8363 & 0,7071 \\
\hline AC & 0,8429 & 0,7659 \\
\hline OCB & 0,8769 & 0,8354 \\
\hline
\end{tabular}

Sumber: Pengelolahan data dengan PLS, 2014

Konstruk dinyatakan reliabel jika memiliki nilai composite reliability di atas 0,70 dan cronbach's alpha di atas 0,60. Dari hasil output SmartPLS di atas semua konstruk memiliki nilai composite reliability di atas 0,70 dan cronbach's alpha di atas 0,60. Jadi dapat disimpulkan bahwa konstruk memiliki reliabilitas yang baik.

\section{Pengujian Model Struktural (Inner Model)}

Model struktural dalam PLS dievaluasi dengan menggunakan $\mathrm{R}^{2}$ untuk variabel dependen dan nilai koefisien path untuk variabel independen yang kemudian dinilai signifikansinya berdasarkan nilai t-statistic setiap path. Adapun model struktural penelitian ini dapat dilihat pada gambar berikut:

Gambar 4.2

Tampilan Hasil PLS Boothstrapping

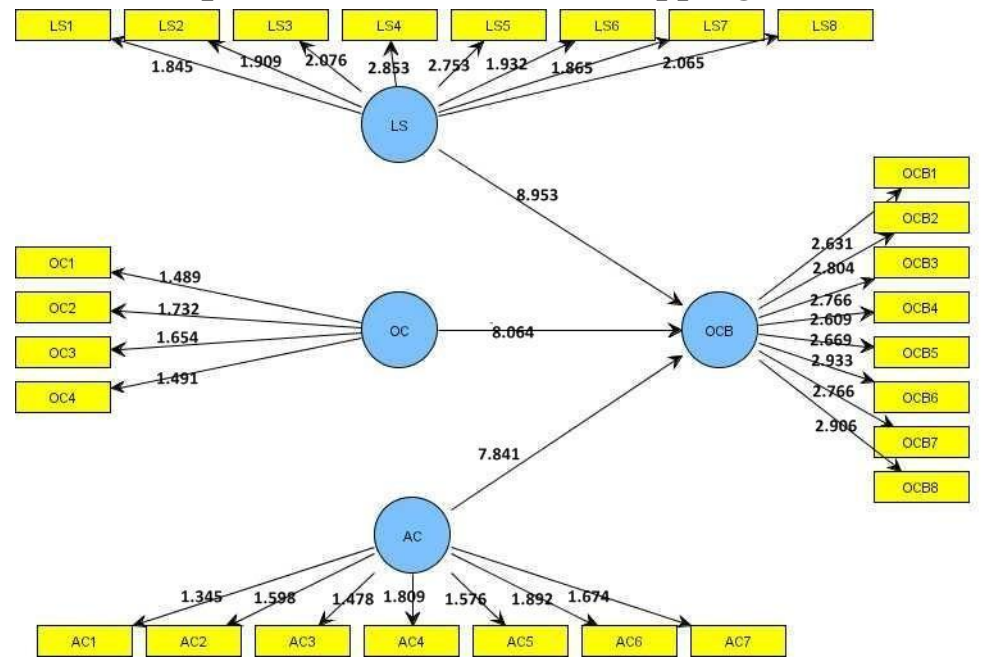

Gambar 4.2 tampilan output model struktural, 2014

Untuk menilai signifikansi model prediksi dalam pengujian model struktural, dapat dilihat dari nilai $t$-statistic antara variabel independen ke variabel dependen dalam tabel Path Coefficient pada output SmartPLS dibawah ini:

Tabel 4.6 
Path Coefficients (Mean, STDEV, t-Value)

Sumber: Pengolahan data dengan PLS, 2014

\section{Pengujian Hipotesis Pengujujian Hipotesis H1}

\begin{tabular}{|c|c|c|c|c|}
\hline & $\begin{array}{c}\text { original } \\
\text { sample } \\
\text { estimate }\end{array}$ & $\begin{array}{c}\text { mean of } \\
\text { subsamples }\end{array}$ & $\begin{array}{c}\text { Standard } \\
\text { deviation }\end{array}$ & $\begin{array}{c}\text { T- } \\
\text { Statistic }\end{array}$ \\
\hline \hline LS $>$ OCB & 0.289 & 0.324 & 0.106 & 2.729 \\
\hline OC $>$ OCB & 0.430 & 0.419 & 0.117 & 3.754 \\
\hline AC $>$ OCB & 0.354 & 0.370 & 0.150 & 2.351 \\
\hline
\end{tabular}

Dari tabel 4.6 di atas dapat dilihat nilai original sample estimete $L S$ adalah sebesar 0,289 dengan signifikansi dibawah 5\% yang ditunjukkan dengan nilai t-statistik 2,726 lebih besar dari nilai t-tabel sebesar 1,962. Nilai original sample estimate positif mengindikasikan bahwa gaya kepemimpinan berpengaruh positif terhadap organizational citizenship behavior. Berdasarkan hasil regresi tersebut dapat disimpulkan bahwa hipotesis pertama diterima.

\section{Pengujujian Hipotesis H2}

Pengujian kedua dilakukan untuk melihat apakah komitmen organisasi $(O C)$ berpengaruh positif terhadap organizational citizenship behavior (OCB). Hasil pengujian dapat dilihat dari tabel 4.6 di atas, $O C B$ memperoleh nilai original sample estimate sebesar 0,4305 dengan nilai t-statistik 3, ). Berdasarkan hasil pengujian AC memperoleh nilai original sample estimate sebesar 0,354 dengan nilai t-statistik 2,351 > 1,962 t-tabel yang berarti variabel akuntabilitas berpengaruh positif sebesar 23,51\% terhadap organizational citizenship behavior dengan signifikansi dibawah 5\% (signifikan). Dari hasil regresi hipotesis tersebut dapat simpulkan bahawa hipotesis ketiga (H3) diterima.

\section{Pembahasan}

\section{Pengaruh Gaya Kepemimpinan terhadap $O C B$}

Berdasarkan hasil pengujian hipotesis pertama dapat disimpulkan bahwa variabel gaya kepemimpinan berpengaruh positif terhadap organizational citizenship behavior. Hal ini sesuai dengan hipotesis yang menyatakan bahwa gaya kepemimpinan berpengaruh terhadap organizational citizenship behavior yang dikembangkan dari hasil penelitian Barbuta dan Schol (1999) yang menemukan bahwa yang dapat mempengaruhi OCB adalah perilaku kepemimpinan, dengan korelasi yang sangat kuat. Hasil penelitian ini konsisten dengan penelitian Organ dan Padsakoff (2006) yang mengemukakan bahwa adanya dukungan dari atasan juga turut mempengaruhi OCB. Dukungan yang diberikan oleh pemimpin dapat memunculkan sikap positif terhadap pekerjaan dan organisasi, serta mempunyai keinginan untuk membantu rekan sekerjanya dan akan lebih kooperatif.

\section{Pengaruh Komitmen Organisasi terhadap Organizational Citizenship Behavior}

Berdasarkan hasil pengujian pada hipotesis kedua menunjukkan bahwa komitmen organisasi juga berpengaruh terhadap organizational citizenship behavior. Komponen utama dari kinerja karyawan untuk orientasi sistem organisasi terdiri dari 
$O C B$, penekanan identifikasi karyawan, loyalitas, komitmen dan memiliki reward individu yang terhubung dengan kinerja organisasi, hasil ini sesuai dengan penelitian Podsakoff et al (2009) yang menyatakan bahwa $O C B$ sangat penting dalam mendukung kinerja organisasi. Hasil penelitian ini konsisten dengan hasil penelitian Riketta dan Landerrer (2002) yang mengemukakan bahwa komitmen organisasi berpengaruh positif terhadap perilaku kerja dalam hal ini $O C B$. Individu yang mempunyai komitmen organisasi afektif yang tinggi akan memiliki niat untuk membalas (reciprocate) untuk organisasi melalui melibatkan diri dalam $O C B$ (Cropanzano et al., 2003).

Lingkungan kerja yang menyuburkan komitmen organisasi akan berkontribusi dengan peningkatan kualitas kerja. Cara anggota TNI melihat lingkungan kerja dapat mempengaruhi kinerja dan lingkungan kerja juga memainkan peran kunci dalam mengembangkan sikap dan perilaku pekerjaan. Menyadari akan pentingnya komitmen organisasi, pemerintah di tahun 2011 mulai memberikan remunerasi yang berupa tunjangan jabatan untuk meningkatkan kesejahteraan anggota TNI, sehingga diharapkan komitmen organisasi semakin tinggi.

\section{Pengaruh Akuntabilitas terhadap Organizational Citizenship Behavior}

Hasil pengujian hipotesis ketiga menunjukkan adanya pengaruh signifikan akuntabilitas terhadap organizational citizenship behavior. Artinya akuntabilitas juga melibatkan harapan atau asumsi bahwa individu akan berperilaku dengan cara tertentu. Jelas bahwa perilaku karyawan mempunyai hubungan dengan akuntabilitas. Kepercayaan dan akuntabilitas tertanam dalam konteks sosial yang berhubungan dengan variabel sosial- psikologis dalam konteks organisasi baik formal maupun informal (Ammeter et al 2004 dalam Hall, et al 2004), dan untuk menciptakan efektifitas organisasi yang berdampak pada peningkatan produktifitas, perlu menciptakan suasana kerja yang memberi peluang munculnya perilaku $O C B$ dikalangan pegawai. Di instansi militer, tuntutan akuntabilitas internal sangat tinggi. Akuntabilitas internal ini diduga dapat menjadi pemicu anggota berperilaku $O C B$.

Menurut Budiyanto (2013) untuk menciptakan efektifitas organisasi yang berdampak pada peningkatan produktifitas, perlu menciptakan suasana kerja yang memberi peluang munculnya perilaku $O C B$ dikalangan pegawai. Di instansi militer, tuntutan akuntabilitas internal sangat tinggi. Akuntabilitas internal ini diduga dapat menjadi pemicu anggota berperilaku $O C B$. Dari sisi akuntabilitas eksternal, dunia militer tidak lagi ekslusif dan tertutup seperti pada era orde baru. Publik menyaksikan dan turut mengawasi kinerja TNI dalam menjalankan tugasnya. Oleh sebab itu, kesadaran anggota TNI akan akuntabilitas eksternal yang harus dipenuhi akan mampu meningkatkan semangat untuk berperilaku $O C B$.

\section{PENUTUP}

\section{Kesimpulan Penelitian}

Penelitian ini memberikan bukti empiris mengenai pengaruh gaya kepemimpinan (leadership style), komitmen organisasi (organization commitment) dan akuntabilitas (accountability) terhadap Organizational Citizenship Behavior (OCB). Penelitian ini menggunakan sampel 170 responden, yang merupakan anggota dan pegawai sipil dan militer di Korem 041/Gamas, Kodim 0401 dan Kompi senapan B kota Bengkulu. Hasil penelitian menunjukkan bahwa:

1. Gaya kepemimpinan (leadership style) berpengaruh terhadap OCB. Dimana gaya kepemimpinan yang efektif dapat meningkatkan atau mendorong seorang pegawai/bawahan bersikap $O C B$ yang lebih besar.

2. Komitmen organisasi berpengaruh terhadap $O C B$. Dimana seorang pegawai/bawahan yang memiliki komitmen terhadap organisasi akan merasa bahagia menjadi bagian 
dari organisasi tersebut, mempunyai kepercayaan dan perasaan yang baik terhadap organisasinya dan memiliki keinginan untuk tetap tinggal dalam organisasi, serta bermaksud untuk melakukan apa yang terbaik bagi organisasi sehingga akan lebih memunculkan $O C B$.

3. Akuntabilitas berpengaruh terhadap $O C B$. Dimana gaya praktik akuntabilitas dalam organisasi dan sikap akuntabilitas internal pegawai atau anggota TNI-AD dapat meningkatkan atau mendorong seorang pegawai memiliki sikap $O C B$ yang lebih besar.

\section{Implikasi Hasil Penelitian}

Hasil penelitian ini menunjukkan adanya pengaruh gaya kepemimpinan, komitmen organisasi, dan akuntabilitas terhadap $O C B$ di beberapa satuan institusi militer di kota Bengkulu. Hasil penelitian ini dapat digunakan oleh Institusi militer (TNIAD) kota Bengkulu untuk dapat mempertahankan gaya kepemimpinan yang telah ada, dan komitmen organisasi serta akuntabilitas dari anggota maupun pemimpin yang sudah baik dapat dipertahankan sehingga perilaku $O C B$ pada institusi tersebut dapat lebih meningkat lagi, selain itu berdasarkan frekuensi jawaban responden untuk variabel gaya kepemimpinan pada pernyataan "Saya merasa bahwa saya bekerja untuk alasan yang lebih besar dari sekedar uang untuk hidup" sebanyak $84,70 \%$ responden memilih jawaban pada skala 4 (setuju), hal tersebut menunjukkan bahwa responden yang memiliki komitmen yang cukup tinggi terhadap organisasi dan perilaku $O C B$ yang cukup tinggi dengan didorong dari gaya kepemimpinan pimpinan institusi mereka.

\section{Keterbatasan Penelitian}

Meskipun peneliti telah berusaha merancang dan mengembangkan penelitian ini sedemikian rupa, namun masih terdapat beberapa keterbatasan dalam penelitian ini yang masih perlu direvisi dalam penelitian selanjutnya, antara lain:

1. Beberapa satuan unit institusi militer dalam penelitian ini tidak dijadikan sampel dikarenakan tidak di izinkan untuk melakukan penelitian, sehingga hasil penelitian ini tidak menyeluruh untuk seluruh satuan institusi.

2. Model penelitian hanya menguji pengaruh variabel/konstruk secara linear, sehingga hasil masih memungkinkan untuk melakukan penelitian dengan menguji hubungan antar variabel dan menggambarkan pengaruh secara keseluruhan.

\section{Saran untuk Penelitian Selanjutnya}

Berdasarkan hasil penelitian yang telah dilakukan, ada beberapa saran yang dapat dipertimbangkan untuk penelitian selanjutnya, yaitu:

1. Penelitian selanjutnya diharapkan dapat melakukan penelitian di semua unit satuan institusi militer sehingga hasil penelitian lebih menyeluruh.

2. Penelitian selanjutnya diharapkan dapat melakukan pengujian dengan model yang lebih dikembangkan, sehingga hasil penelitian dapat lebih memberi gambaran yang lebih baik.

\section{DAFTAR PUSTAKA}

Akbar, R.2011.Performance Measurement and Accountability in Indonesian Local Governmen. Desertasi Curtin University.

Ariani, D.W.2011. Hubungan antara Perilaku Kewarganegaraan Organisasional dan Kinerja Tugas. Jurnal manajemen teori dan terapan, tahun 4 No1. 
Bolino, M.C. Turnley, W.H,. dan Bloodgood, J.M. 2002. Citizenship Behavior and The Creation of Social Capital in Organizations. Academy of Management Review 27: 505-522.

Bovens, M. 2007. New Forms of Accountability and EU-governance. Comparative Europeanpolitics 5: 104-120.

Budiyanto.2013. Pengembangan Organisasi Sektor Publik (Pemerintah) dengan Pendekatan Organizational Citizenship Behavior (OCB). Orasi Ilmiah Dies Natalis ke 41 STIESA.

Camilleri, E. dan Heijden, B.V. 2007.Organizational Comitment, Public Service Motivation and Performance Within The Public Sector. Public Performance and Managerial Review Vol 31 No 2.

Chen, C.Y,. dan Yang, C.F. (2012). The Impact of Spiritual Leadership on Organizational Citizenship Behavior: A multi Sample Analysis. J bus ethics 105: 107-114.

Cooper, D. R. dan Schindler, P. S. 2011. Business Research Methods. Edisi 11. New York. NY: McGraw-Hill.

Cropanzano, R., Rupp, D. E., \& Byrne, Z. S. 2003. The relationship of emotional exhaustion to work attitudes, job performance, and organizational citizenship behaviors. The Journal of Applied Psychology 88: 160-1690.

Fry, L.W., Hannah, S.T. Noel, M. dan Walumbwa, F.O.2011. Impact of Spiritual Leadership on Unit Performance. The leadership Quarterly 22:259- 270.

Hall, A.T., Blass, F.R., Ferris, G.R., dan Massengale, R. 2004. Leader Reputation and Accountability in Organizations: Implications For Disfunctional Leader Behavior. The Leadership Quartely15:515-536.

Hartati, Karina.2008.Pandangan Publik Terhadap Akuntabilitas Pemerintah Daerah Di Provinsi Jawa Tengah.Universitas Diponegoro:Semarang.

Indrianto, N dan Supomo, B. 1999. Metodologi Penelitian Bisnis untuk Akuntansi dan Manajemen. Yogyakarta: BPFEB-UGM.

Jogiyanto, 2007. Sistem Informasi Keperilakukan. Yogyakarta: Penerbit ANDI Jogiyanto, H.M. dan Abdillah, W. 2009. Konsep dan Aplikasi PLS (partial least square) untuk penelitian empiris. Yogyakarta: BPFE- YOGYAKARTA.

Mahmudah, Hadi. dan Mapuasari, Supeni.(2013). Komitmen Organisasi, Akuntabilitas dan Organization Citizenship Behavior Institusi Militer Di Indonesia. Simposium Nasional Akuntansi XVI Manado, 25-28 September 2013.

Mardiasmo."Otonomi Daerah sebagai upaya memperkokoh Perekonomian Daerah", Jurnal Ekonomi Rakyat Th I No. 4, Juni 2002

Moynihan, D.P. dan Pandey, S.K. 2007.The Role of Organizations in Fostering Public Service Motivation'. Public Administration ReviewVol 67 No.1.

Podsakoff, N.P, Blume, B.D, Whiting, S.W, dan Podsakoff, P.M. 2009. Individual and Organizatio Level Consequencesof Organizational Citizenship Behaviours: A Meta Analysis. Journal of Applied Psychology, 94, 122-141.

Rayner, J. Lawton, A. dan Williams, H. M. 2012. Organizational Citizenship Behavior and Public Service Ethos: Whither the Organization?. J Bus Ethics 106: 117-130.

Riketta, M. dan Landerer, A. 2002. Organizational Commitment, Accountability and Work Behavior: A Correlation Study. Social Behavior and Personality 30 (7): 653660.

Sinclair, Amanda. 1995. The Chameleon of Accountability : Forms and Discourses. Accounting, Organization, and Society, vol. 20 no.2/3. Pp 219-237.

Williams, Guy L.J dan Anderson.1991. Job Satisfaction and Organizational Commitment as Predictors of Organizational Citizenship and in Role- Behaviors. Journal of Management 17:601. 